\title{
27. NATURE AND SIGNIFICANCE OF VOLCANOGENIC DEPOSITS AT THE EOCENE/OLIGOCENE BOUNDARY, HOLE 593, CHALLENGER PLATEAU, TASMAN SEA ${ }^{1}$
}

\author{
Campbell S. Nelson, Roger M. Briggs, and Peter J. J. Kamp, University of Waikato ${ }^{2}$
}

\begin{abstract}
Hole 593 includes a spectacular 16.4-m-sequence of thinly bedded, grayish black, lithified volcanogenic sandstones, mudstones, and occasional breccias near its base within chalks. Sandstone-mudstone couplets (up to $50 \mathrm{~cm}$ thick) have sharp basal contacts, are normally graded, and include Bouma A, B, occasional C, and E divisions, whereas brecciadominated units are thicker (up to $140 \mathrm{~cm}$ ), massive or inversely graded, and unsorted. The beds were deposited rapidly at bathyal depths, close to the Eocene/Oligocene boundary, from turbidity currents and/or subaqueous pyroclastic flows originating on the slopes of "Lalitha pinnacle," a now-buried $\sim 500$-m-high volcanic shield (average 6-8 ${ }^{\circ}$ slopes) located only $\sim 3 \mathrm{~km}$ from Site 593 .

The occurrence in the deposits of rare primary augite and olivine crystals, the abundance of the low $\mathrm{Si} / \mathrm{Al}$ zeolite phillipsite, and certain chemical considerations support a basaltic parentage. However, as a result of low-temperature oxidative alteration by pore fluids following emplacement, the original basaltic glass fragments that formed the bulk of the deposits have been palagonitized extensively and replaced by phillipsite, smectite, and calcite.

"Lalitha pinnacle" is similar to several other (buried) "pinnacles" evident on seismic records from southern Lord Howe Rise, both in its seismic character and structural and age relations to surrounding sediments. This suggests that submarine basaltic volcanism and associated sedimentary redeposition was widespread in the southeast Tasman Sea during the late Eocene to early Oligocene. The activity is viewed as off-rift (western) volcanism that is related to regional extension and the formation of a major western New Zealand rift system associated with eastward propagation of the mid-ocean Southeast Indian Ridge into the south Tasman Sea and through the New Zealand subcontinent at this time. Analogous occurrences of submarine Eocene-Oligocene basalts east of the rift system now crop out on land in eastern South Island, New Zealand.
\end{abstract}

\section{INTRODUCTION}

Nearly all of the record total of about 3700 m of sediment cored on DSDP Leg 90 at eight sites (587-594) in the southwest Pacific consisted of middle to late Cenozoic calcareous oozes and chalks. On two counts the sequence encountered at the bottom of Hole 593 generated considerable shipboard interest. First, it was one of only three holes to penetrate Eocene strata. Second, the Eocene chalks included a conspicuous 16.4-m-thick sequence of dark-colored volcanogenic deposits, the only relatively thick nonbiogenic lithology cored on Leg 90 . In this chapter, we describe briefly the stratigraphy and nature of the volcanogenic materials, present chemical analyses of bulk samples and mineral separates, and speculate on the tectonic and environmental significance of the volcanics in the southwest Pacific region.

Site $593\left(40^{\circ} 30.47^{\prime} \mathrm{S}, 167^{\circ} 47.48^{\prime} \mathrm{E}\right)$ was drilled in $1068 \mathrm{~m}$ water depth near the western edge of Challenger Plateau, southern Lord Howe Rise, Tasman Sea (Fig. 1). Hole 593 was continuously cored with the hydraulic piston corer from 0 to $245.1 \mathrm{~m}$ sub-bottom and continued to a total depth of $571.5 \mathrm{~m}$ with the extended core barrel. The volcanic sequence is contained within the bottom three cores (Cores 58-60) from 542.7 to $571.5 \mathrm{~m}$ sub-bottom, for which recovery rate averaged about $70 \%$.

\footnotetext{
${ }^{1}$ Kennett, J. P., von der Borch, C., et al., Init. Repts. DSDP, 90: Washington (U.S. Govt, Printing Office).

2 Addresses: Department of Earth Sciences, University of Waikato, Private Bag, Hamilton, New Zealand.
}

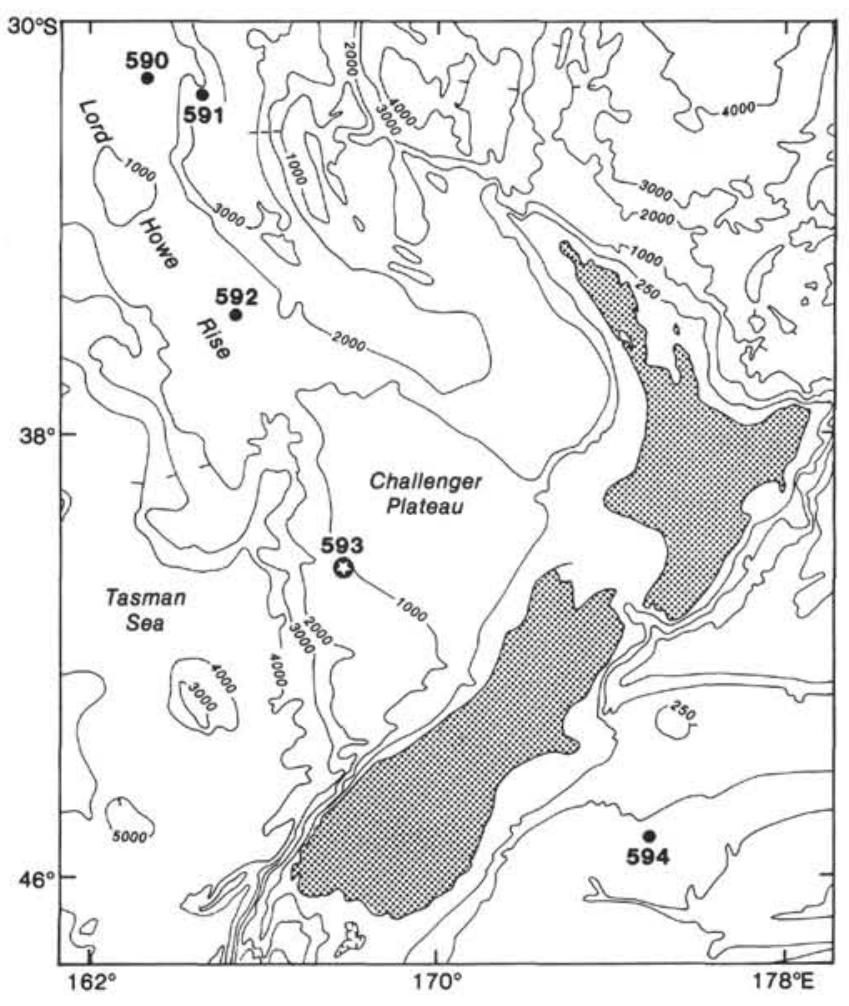

Figure 1. Location of Site 593 on western Challenger Plateau, west of New Zealand. 


\section{THE VOLCANOGENIC SECTION}

\section{Lithostratigraphy}

The volcanogenic sequence is illustrated in Figure 2 and a summary lithologic log, showing "cyclic" units and sample locations, in Figure 3.

The lowermost Core $60(561.9-571.5 \mathrm{~m})$ is white (N9) to light greenish gray (5GY 8/1) foraminifer-bearing nannofossil chalk with many pale green $(10 \mathrm{G} 8 / 1)$ thin $(<2$ $\mathrm{mm}$ ) laminae, possibly altered basic tephra layers (Gardner, Nelson, et al., this volume). The chalk includes three prominent, thin $(5-20 \mathrm{~cm})$ interbeds of grayish black (N2 to N5), massive to horizontally laminated, volcanogenic fine sandstone and mudstone, the lower two of which are normally graded and burrowed.

Core $59(552.3-561.9 \mathrm{~m})$ and the basal $1.5 \mathrm{~m}$ of Core 58 (542.7-552.3 m) comprise a thinly bedded sequence of lithified volcanogenic breccias, sandstones, and mudstones, which, despite some disturbance by drilling (cf. Leggett, 1982), retain their stratigraphic entity (Fig. 2). Overall, grayish black (N2) colors dominate, although many of the sandstones have distinctive dark greenish hues (5G 2/1, greenish black; $5 \mathrm{G} 6 / 1$, greenish gray; $5 \mathrm{G}$ $3 / 2$, dusky green) and some are rather paler green (5GY $3 / 2$ and $10 \mathrm{G} 4 / 2$, grayish green; $10 \mathrm{Y} 6 / 2$, pale olive). Locally, the darker-colored beds include subtranslucent white or very pale green blotches (Fig. 4) of secondary calcite, smectite, and/or zeolite. Gross variations of grain size are used to subdivide the sequence into a repetitive series of fining-upward sandstone-mudstone units, each ranging from only a few to as much as $50 \mathrm{~cm}$ thick (Figs. 3, 4). The lower boundary of each cyclic unit is usually sharp and sometimes wavy, with relief up to 1 $\mathrm{cm}$, suggestive of predepositional erosion and/or postdepositional loading. The immediately overlying sandstone is mainly massive and medium to fine grained, rarely coarse grained. The sandstone fines upward, develops horizontal laminae, and passes gradationally or abruptly into massive or horizontally laminated, and sometimes convolute-laminated, vitric siltstones or mudstones, superficially resembling black obsidian (Fig. 4). Unit boundaries are not always clear, and several of those numbered in Figure 3 (e.g., Units 24, 26, and 31) are composite. The sharp basal contacts, normal grading, and presence of Bouma $\mathrm{A}, \mathrm{B}$, occasional $\mathrm{C}$, and $\mathrm{E}$ divisions indicate that the majority of the sandstonemudstone couplets are turbidity current deposits that originated as either cold sedimentary (e.g., Walker, 1979) or pyroclastic flows (e.g., Lajoie, 1979).

In contrast, at least five of the coarser-grained units (i.e., Units 18, 20, 21, 27 and 29), including three thick $(40-139 \mathrm{~cm})$ breccia beds, generally coarsen upward and support a thin capping mudstone. The breccias comprise an unsorted assemblage of clast-supported, angular, black glassy fragments, up to $8 \mathrm{~mm}$ in size, in a dark glassy interstitial matrix of sand and mud. They are mainly massive, although the more sandy portions at the base may include poorly developed horizontal laminations. The lithology and structure of these thicker, inversely (-to-normally) graded coarse units are consistent with them being either sedimentary mass flow deposits (e.g., Carter,
1975) or primary subaqueous pyroclastic flows (e.g., Lajoie, 1979) of more proximal aspect than the associated sandstone-mudstone couplets.

Veins of white sparry calcite are locally conspicuous, especially in the fine-grained tops of cyclic units (Figs. 2 to 4$)$. They are 0.1 to $4 \mathrm{~mm}$ wide, most form subhorizontal anastomosing stringers parallel to bedding, and some heal high-angle tension cracks. The subhorizontal veins possibly originated by recrystallization of thin layers of interbedded calcareous ooze, an interpretation supported by the close association of veining with partly recrystallized ooze layers near the top of Section 59358-3 (Fig. 2).

The uppermost contact of the volcanogenic deposits at $545.5 \mathrm{~m}$ sub-bottom depth is sharp and irregular (Fig. 2). It is overlain by homogeneous, white (N9) to very light gray (N8) nannofossil ooze, alternating in consistency from firm to stiff, with no megascopic volcanic components.

\section{Age}

The preliminary fossil evidence (Site 593 report, this volume) indicates that the volcanogenic deposits straddle the Eocene/Oligocene boundary (Fig. 5). The planktonic foraminiferal data place the Eocene/Oligocene boundary a few centimeters above the volcanic material, at about Sample 593-58-2, $120 \mathrm{~cm}$. On the other hand, the boundary as defined by the extinction of two calcareous nannoplankton species occurs within the volcanic sequence, between Units 19 and 34. At Site 592 to the north, which contains an excellent extended ooze sequence over the boundary, the critical nannofossil species also disappear about $7 \mathrm{~m}$ below the zonal planktonic foraminiferal species. Thus, the microfossil succession appears uninterrupted, a view supported by continuity of a uniformly low sedimentation rate of $4.6 \mathrm{~m} / \mathrm{m}$.y. (Site 593 report, this volume) across the boundary. The best age estimate for emplacement of the volcanogenic deposits is very latest Eocene to possibly earliest Oligocene. This is consistent with the reversed geomagnetic polarity values throughout the volcanogenic sequence (Site 593 report, this volume), suggesting deposition during magnetic Subchron C13R, 37-36 m.y. ago (LaBrecque et al., 1983; Poore et al., 1983). The volcanic material is too altered to provide a reliable radiometric age (I. McDougall, pers. comm., 1983).

\section{Petrography}

Eleven small samples (S1-S11) representative of a range of textures and structures in the volcanogenic sequence were slabbed from coherent core sections aboard ship (Fig. 3).

In thin section the rock fabrics are varied and complex, their most obvious feature being the abundance of brown palagonite (cf., Hay and Iijima, 1968). Alteration is such that original clastic textures are often difficult to distinguish (Plate 1, Fig. 1). In one sample (S9) relict outlines of glass shards are discernible (Plate 1, Fig. 2), where cuspate curved vitric fragments are concentrated in thin layers (Plate 1, Fig. 3), possibly representing primary volcanic ash. All other samples show 


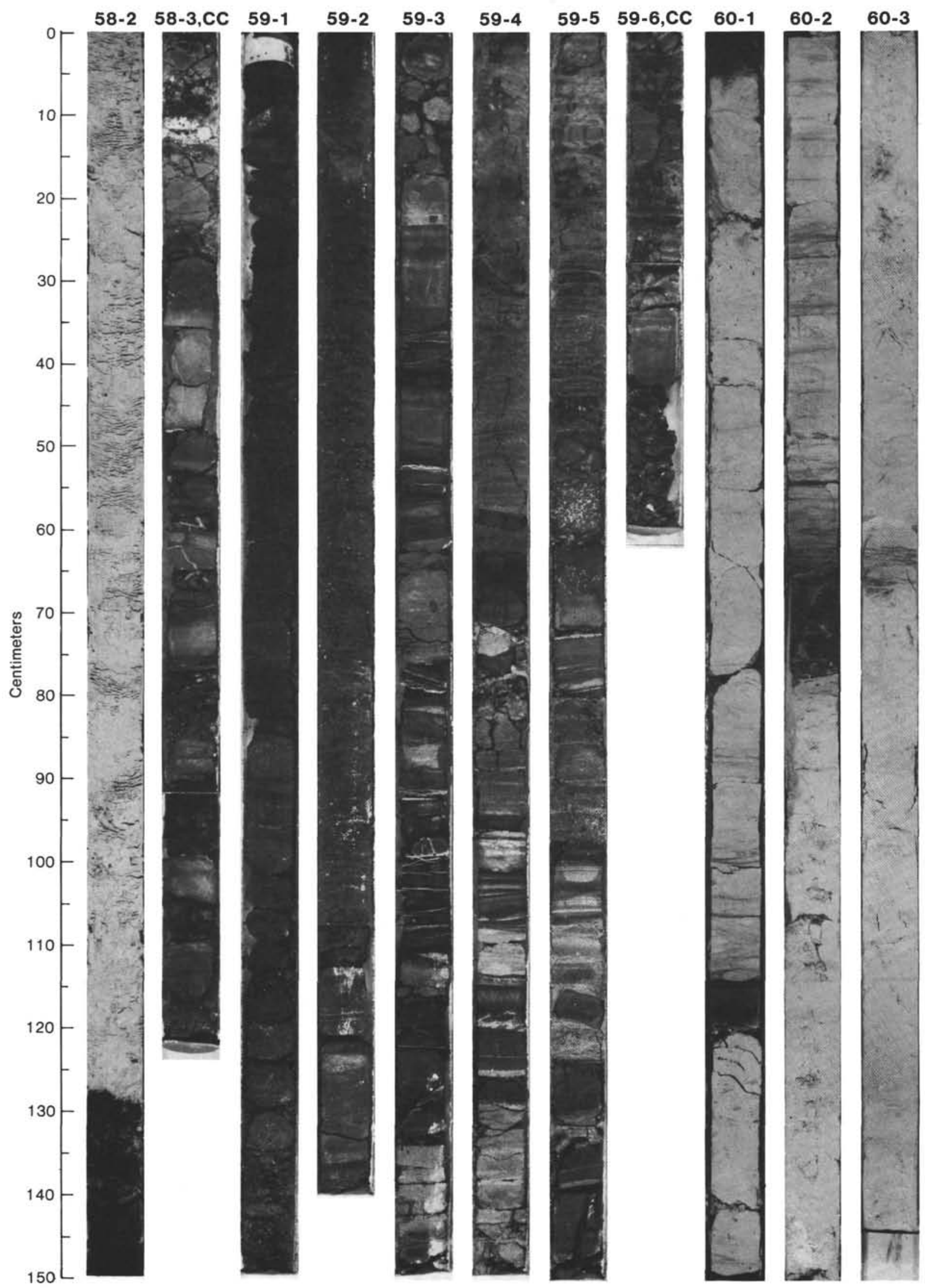

Figure 2. The recovered volcanogenic sequence within Paleogene chalk from the basal three cores (544.2-566.4 m sub-bottom) in Hole 593. Based on key foraminifers, the Eocene/Oligocene boundary occurs at about Sample 593-58-2, $120 \mathrm{~cm}$, whereas critical nannofossil species suggest the same boundary is in Core 59 . 


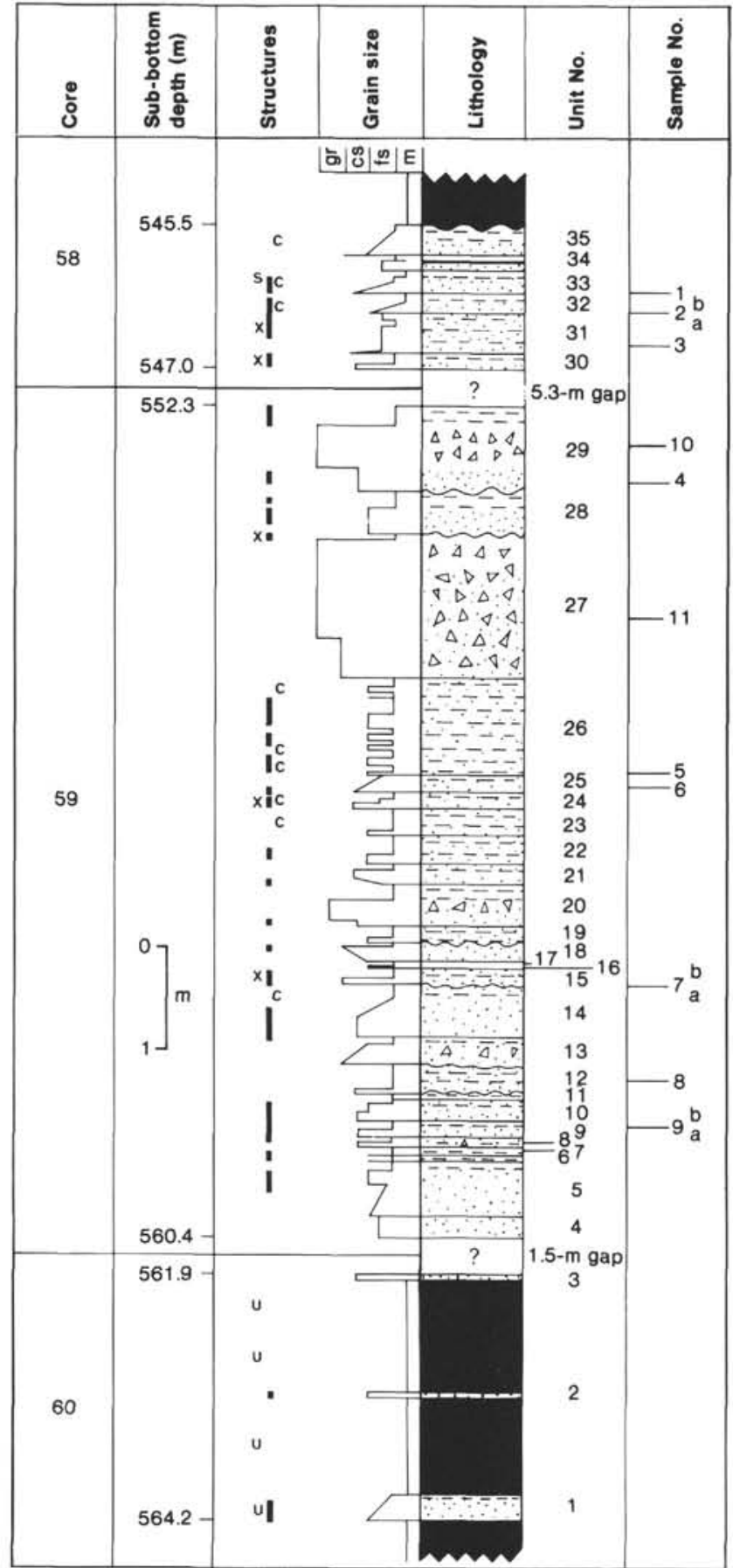

Lithology

Calcareous ooze/chalk

$4 \nabla^{4}$ Volcanogenic breccia

Structures

I Horizontal laminations

$x$ Cross laminations

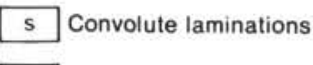

$u$ Bioturbate structures

c Prominent calcite veins

Figure 3. Lithologic log of the volcanogenic sequence at the base of Hole 593 showing sample positions and sedimentation units defined on the basis of size grading and contact types. Modal sizes are: $\mathrm{gr}=\operatorname{gravel}(>2.0 \mathrm{~mm}), \mathrm{cs}=$ coarse sand $(0.5-2.0 \mathrm{~mm}), \mathrm{fs}=$ fine sand $(0.06-0.5 \mathrm{~mm}), \mathrm{m}=\operatorname{mud}(<0.06 \mathrm{~mm})$. blotchy, globular, or spherulitic masses of dark brown palagonitic material, with irregular patches of the secondary minerals calcite, phillipsite, and smectite (Plate 1, Figs. 4, 5). The lithologic layering evident from color and grain-size variations in the core (Fig. 2) corresponds to variations in the abundance of palagonite and secondary minerals in the deposits. In particular, the lighter gray coarser sediment intervals are relatively enriched in coarsely crystalline sparry calcite (Plate 1, Fig. 6), and sometimes phillipsite, probably because of the originally coarser grain size and higher porosity of the primary volcanogenic sediment at these levels. Compared to the coarser-grained sediments, the associated mudstones (e.g., $\mathrm{S} 2 \mathrm{a}, 5,7 \mathrm{a}$, and $9 \mathrm{a}$ ) are relatively enriched in smectite and phillipsite, but depleted in calcite (confirmed by semiquantitative $\mathrm{x}$-ray diffraction data).

The only primary minerals observed in thin section are occasional pale green prismatic or anhedral augite up to $0.1 \mathrm{~mm}$ in length, and a single tiny grain of olivine. Magnetite is a minor constituent and occurs as small $(0.02 \mathrm{~mm})$ irregular anhedral grains. Feldspar is absent. Occasionally foraminifers occur in the palagonitic mudstone beds (Plate 1, Fig. 7).

Palagonite varies in color from buff, brown, dark brown to black and occurs either as irregular blotchy masses or in globular, spherulitic, or colloform habit (Plate 1). Some globules or spherulites show a zonal concentric arrangement from phillipsite or calcite cores to outer layers containing smectite or calcite, and an outermost selvage of palagonite (Plate 1, Fig. 8); however, this secondary mineralogic sequence is highly variable. Also, some cores of aggregated globular palagonite may consist of a single secondary mineral, so that globules containing calcite or smectite or phillipsite may be adjacent to each other in the aggregate (Plate 1, Fig. 4), suggesting that extensive metasomatism between palagonite globules has taken place. Radial cracks in globular or spherulitic masses are common features, and many massive palagonite patches contain curved perlitic cracks. Such microfractures probably allowed seawater extensively to pervade the deposits; this has enhanced secondary alteration.

Smectite is a common secondary mineral, has a light to dark green color, and forms irregular patches within palagonite, cross-cutting veins, or globules, the latter probably representing pseudomorphs after globular palagonite.

Phillipsite is colorless to yellow, and its presence has been confirmed by x-ray diffraction (XRD) and microprobe data. The composition of phillipsite in $\mathrm{S} 5$ is given in Table 1; it has a Si/Al ratio of 2.49 , consistent with $\mathrm{Si} / \mathrm{Al}$ ratios in the range 2.44-2.87 for deep-sea phillipsites generally (Boles, 1977). The $\mathrm{Na}_{2} \mathrm{O}$ content is probably low because of volatilization under the probe beam. Phillipsite forms radiating splays in patches and pools (Plate 1, Fig. 9) and in globules after palagonite.

Calcite is ubiquitous and often abundant and occurs as irregular aggregates, rounded masses after palagonite, coarsely crystalline pseudospar, or as stringers and veins that both parallel and cross cut bedding. The calcite is a low magnesian variety; microprobe analyses of two calcites gave $\mathrm{MgO}$ contents of $0.84-0.94$ wt.\%, total $\mathrm{Fe}$ as 


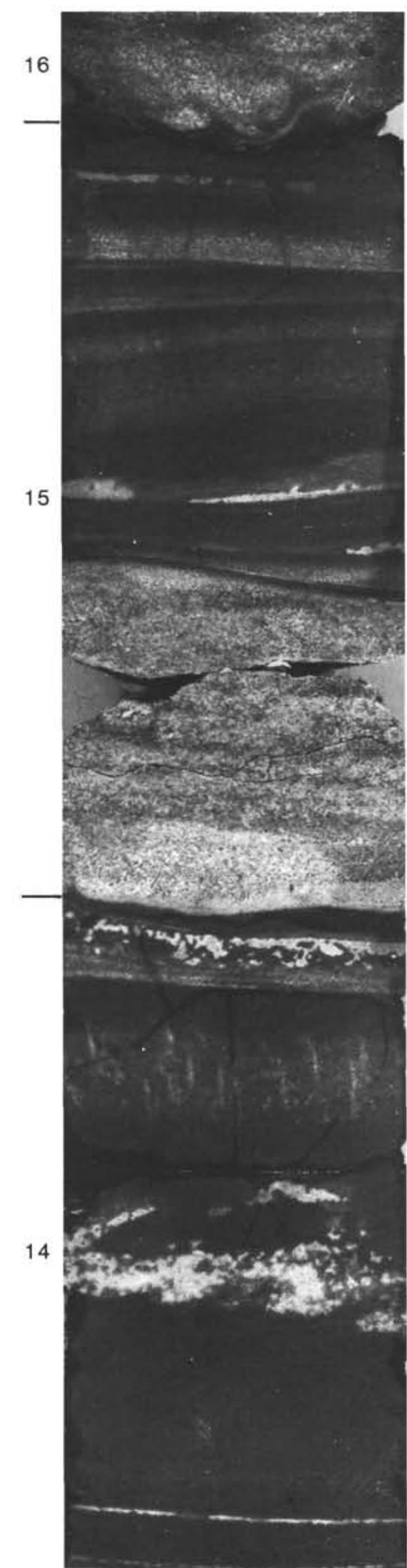

A

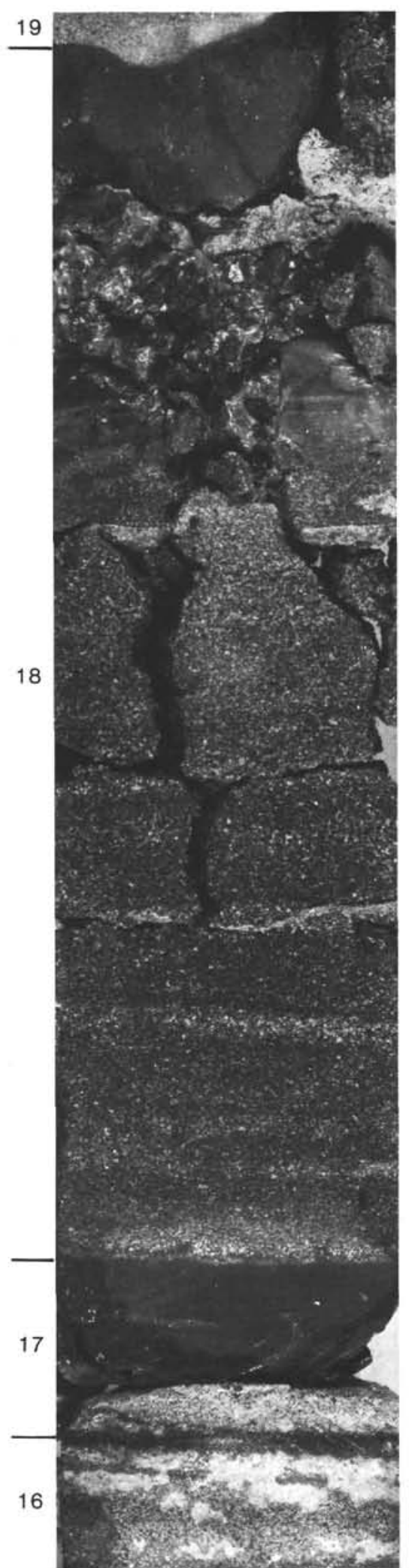

B

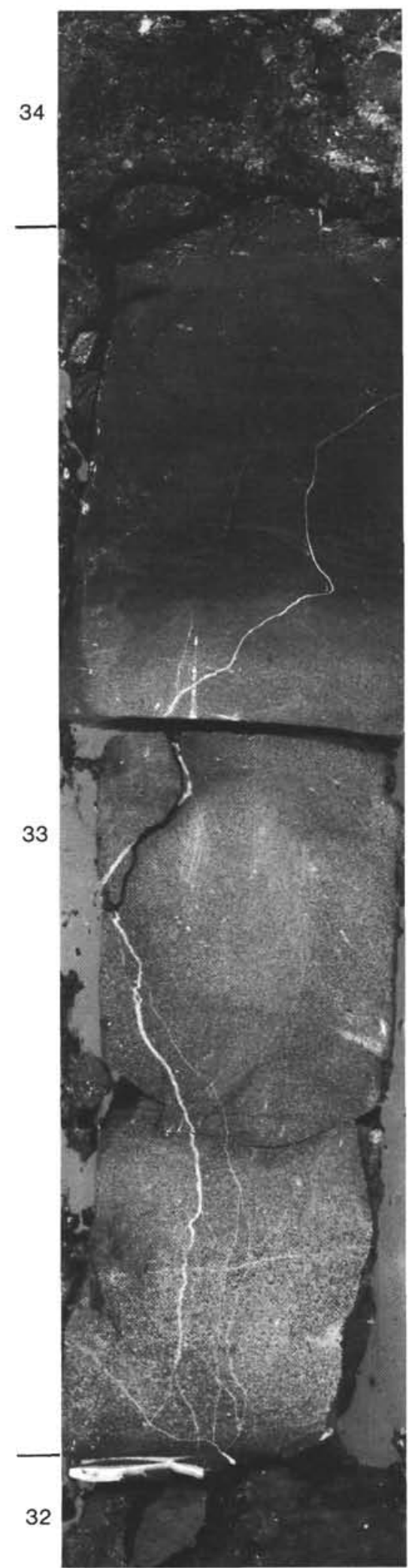

C

Figure 4. Closeup of lithologies and structures typical of Hole 593 volcanogenic deposits. Core sections are $25 \mathrm{~cm}$ long each, and unit numbers (see Fig. 3) are indicated. (A) From Sample 593-59-4, 100-125 cm showing light-colored, vaguely laminated sandstones forming the lower part of Units 15 and 16 in sharp lower contact with massive, laminated or cross-laminated, dark vitric siltstones and mudstones, those in Unit 14 including light blotchy areas due to concentrations of secondary calcite and zeolite. (B) From Sample 593-59-4, 75$100 \mathrm{~cm}$ showing massive laminated sandstones with thin, massive, dark mudstones. Note the sharp, irregular contact between Units 18 and 19. (C) From Sample 593-58-3, 25-50 cm showing sharp lower and upper contacts, normal grading, some horizontal and convolute laminae, and both horizontal and vertical calcite veining in Unit 33. 


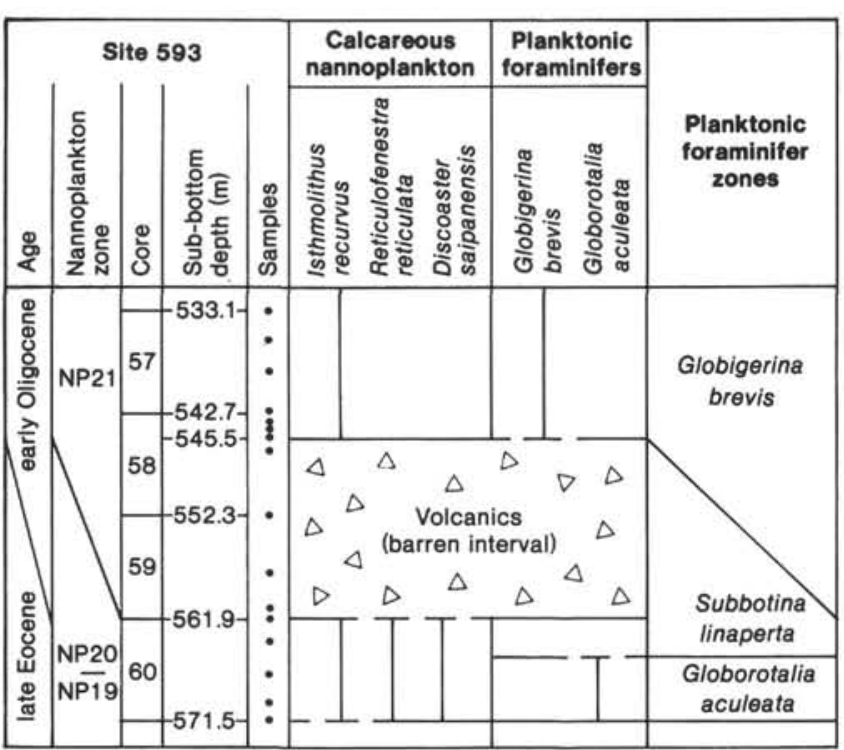

Figure 5. Distribution of key planktonic foraminiferal and nannofossil species used to define the Eocene/Oligocene boundary in relation to the volcanogenic deposits near the base of Hole 593. The occurrence of Isthmolithus recurvus shows the core terminated in sediments no older than the late Eocene NN19 Zone. The absence of Sphenolithus pseudoradians prevents recognition of the NN20/ NN19 boundary. The last occurrence of Reticulofenestra reticulata (= Cribrocentrum reticulatum) and Discoaster saipanensis marks the Eocene/Oligocene boundary.

Table 1. Microprobe analysis of phillipsite in Sample 593-59-3, 60 cm (Sample 5, Fig. 3).

\begin{tabular}{|c|c|c|}
\hline & & Cations on basis of $31(0)$ \\
\hline $\mathrm{SiO}_{2}$ & 51.40 & 11.16 \\
\hline $\mathrm{Al}_{2} \mathrm{O}_{3}$ & 17.54 & 4.49 \\
\hline $\mathrm{FeO} *{ }^{\circ}$ & 1.29 & 0.24 \\
\hline $\mathrm{MgO}$ & 0.10 & 0.03 \\
\hline $\mathrm{CaO}$ & 0.14 & 0.03 \\
\hline $\mathrm{Na}_{2} \mathrm{O}$ & 3.71 & 1.56 \\
\hline $\mathrm{K}_{2} \mathrm{O}$ & 6.26 & 1.74 \\
\hline $\mathrm{H}_{2} \mathrm{O}$ & n.d. & - \\
\hline Total & 80.44 & $\mathrm{Si} / \mathrm{Al}$ \\
\hline
\end{tabular}

Note: ${ }^{*}=$ total Fe. n.d. $=$ not determined.

$\mathrm{FeO}$ of $0.57-0.69$ wt. $\%$, and $\mathrm{MnO}$ abundances of $0.33-$ 0.44 wt. $\%$.

Iron oxy-hydroxides occur as alteration products of magnetite and in veins associated with calcite.

\section{Major Element Chemistry}

Several samples were analyzed in an attempt to determine the original composition of the volcanogenic material. Five samples of palagonite separates and five whole-rock samples were analyzed by routine $x$-ray fluorescence (XRF) methods, and palagonite material was analyzed by microprobe in eight samples. The microprobe analyses were determined first, and when these showed widely variable compositions, it was considered that although large-scale metasomatism had obviously occurred, analyses of whole-rock samples might be closer to the original composition. However, this was proved not to be the case, and because of the extreme variability in composition of all oxides, only averaged analyses are shown together with ranges in composition in Table 2.

The microprobe analyses of palagonite indicated that intrasample variation was as much as the variation between samples, and no sensible trends in composition with respect to stratigraphic position of the samples could be detected. The very large loss on ignition (LOI) values of samples analyzed by XRF indicate that extensive hydration has occurred. Samples with the largest $\mathrm{CaO}$ contents are also those with the largest LOI values, suggesting that calcite was probably a significant constituent, especially in bulk samples.

\section{Nature of Primary Volcanic Materials}

The major element compositions of the volcanogenic material show that it is severely altered and hydrated, and none of the analytical data are considered to represent the primary composition of the volcanogenic material. However, the glass is thought to have been most likely basaltic rather than andesitic or rhyolitic in composition for the following reasons:

1. Unaltered pale green augite, minor magnetite, and rare olivine are the only primary minerals present. If the original composition of the material was silicic or intermediate, then feldspars would be expected. We have not detected any textural evidence to indicate that feldspar was formerly present but now completely altered. Orthopyroxene is also absent. Hence, a mineralogy dominated by augite favors an original basaltic composition.

2. Most studies on low-temperature oxidative alteration and weathering of basaltic glass by seawater (e.g., Hart, 1970; Scheidegger and Corliss, 1981) indicate there is depletion in $\mathrm{MgO}, \mathrm{SiO}_{2}$, and $\mathrm{CaO}$, and enrichment in $\mathrm{K}_{2} \mathrm{O}$, total iron, $\mathrm{TiO}_{2}, \mathrm{P}_{2} \mathrm{O}_{5}, \mathrm{MnO}$, and $\mathrm{Na}_{2} \mathrm{O}$, whereas $\mathrm{Al}_{2} \mathrm{O}_{3}$ is little affected. These changes in major element abundances, caused by oxidative seawater alteration, are

Table 2. Chemical composition of bulk samples (XRF), palagonite-enriched samples (XRF), and palagonitic material (microprobe) from the volcanogenic deposits at Site 593.

\begin{tabular}{|c|c|c|c|c|c|c|}
\hline & \multicolumn{2}{|c|}{$\begin{array}{l}\text { Composition (XRF) of } \\
\text { bulk samples }(N=5)\end{array}$} & \multicolumn{2}{|c|}{$\begin{array}{c}\text { Composition (XRF) of } \\
\text { palagonite-enriched } \\
\text { samples }(N=5)\end{array}$} & \multicolumn{2}{|c|}{$\begin{array}{c}\text { Composition (microprobe) } \\
\text { of palagonite }(N=8)\end{array}$} \\
\hline & Average & Range & Average & Range & Average & Range \\
\hline $\mathrm{SiO}_{2}$ & 32.28 & $24.26-41.57$ & 39.38 & $31.97-43.80$ & 41.37 & $31.42-49.92$ \\
\hline $\mathrm{TiO}_{2}$ & 2.44 & $2.07-2.70$ & 2.64 & $2.38-2.93$ & 3.30 & $0.34-6.54$ \\
\hline $\mathrm{Al}_{2} \mathrm{O}_{3}$ & 9.47 & $7.53-11.93$ & 10.81 & $9.67-11.96$ & 13.32 & $8.31-18.38$ \\
\hline $\mathrm{FeO}^{*}$ & 9.28 & $7.05-12.38$ & 12.44 & $7.90-15.22$ & 10.43 & $4.15-17.08$ \\
\hline $\mathrm{MnO}$ & 0.17 & $0.09-0.25$ & 0.09 & $0.03-0.21$ & 0.08 & $0.01-0.30$ \\
\hline $\mathrm{MgO}$ & 7.96 & $4.85-12.12$ & 9.75 & $5.54-13.96$ & 6.87 & $3.33-11.33$ \\
\hline $\mathrm{CaO}$ & 16.02 & $5.34-24.61$ & 7.68 & $2.32-18.26$ & 2.71 & $0.43-11.25$ \\
\hline $\mathrm{Na}_{2} \mathrm{O}$ & 2.48 & $1.43-2.99$ & 2.53 & $2.11-2.86$ & 1.82 & $1.01-2.93$ \\
\hline $\mathrm{K}_{2} \mathrm{O}$ & 0.96 & $0.49-1.41$ & 1.09 & $0.30-3.28$ & 1.26 & $0.36-2.33$ \\
\hline $\mathrm{P}_{2} \mathrm{O}_{5}$ & 1.13 & $0.83-1.58$ & 1.32 & $0.86-2.06$ & n.d. & \\
\hline LOI & 17.73 & $10.21-22.79$ & 12.06 & $6.54-18.25$ & n.d. & \\
\hline Total & 99.92 & & 99.79 & & 81.13 & \\
\hline \multicolumn{7}{|l|}{$\mathrm{ppm}$} \\
\hline $\mathrm{Sc}$ & 22 & $18-25$ & 20 & $14-22$ & & \\
\hline v & 207 & $196-228$ & 213 & $128-251$ & & \\
\hline $\mathrm{Cr}$ & 103 & $33-250$ & 111 & $22-274$ & & \\
\hline $\mathrm{Ba}$ & 744 & $259-1209$ & 323 & $101-889$ & & \\
\hline
\end{tabular}

Note: $*$ = total Fe. $\mathrm{LOI}=$ loss on ignition. n.d. $=$ not determined. XRF analyses by $\mathrm{K}$. Palmer, Analytical Facility, Victoria University, Wellington. 
very significant and are suggested by the extreme variation in composition in our samples. Conversely, higher temperature nonoxidative hydrothermal alteration of basalts can produce slight enrichments in the alkali metals, $\mathrm{TiO}_{2}$, and $\mathrm{MgO}$, and depletion in total iron (Campsie et al., 1983).

Because our samples were recovered from within $600 \mathrm{~m}$ of the seafloor, we assume that palagonitization resulted from oxidative low-temperature, low-pressure alteration by pore fluids, and so depletion of $\mathrm{MgO}$ is more likely. The smallest averaged $\mathrm{MgO}$ content is $6.87 \mathrm{wt} . \%$ in palagonite determined by microprobe (Table 2), and the total range in $\mathrm{MgO}$ abundance is $3.3-11.3 \mathrm{wt} . \%$. If $\mathrm{MgO}$ depletion has occurred, then the original composition is more likely to be basaltic rather than andesitic because the average MORB contains 7.6 wt. $\% \mathrm{MgO}$, whereas the average andesite contains only $3.6 \mathrm{wt} . \% \mathrm{MgO}$ (Gill, 1981).

Furthermore, although Sc and V abundances (average 21 and $210 \mathrm{ppm}$, respectively) are not considered diagnostic because these values by themselves could represent either abundances in a basaltic or andesitic composition, the average $\mathrm{Cr}$ content (107 ppm) is regarded as more typical of a basaltic composition. Le Roex and Dick (1981) noted that $\mathrm{Cr}$ (and V) in basalts are relatively unaffected by alteration processes, and so these $\mathrm{Cr}$ contents are unlikely to represent enriched values. Also, most andesites, apart from some continental medium- and high-K calcalkaline varieties, have $\mathrm{Cr}$ abundances less than about $40 \mathrm{ppm}$ (Gill, 1981), whereas $\mathrm{Cr}$ abundances in excess of $100 \mathrm{ppm}$ are typical of basalts.

3. Phillipsite is the only zeolite identified, and clinoptilolite has notably not been detected. In a review of zeolites in deep-sea sediments, Kastner (1979) concluded that phillipsite almost always coexists with basaltic glass. Petzing and Chester (1979) also found that the Si/Al ratio of the parent glass in marine environments generally controlled the type of zeolitic alteration product; phillipsite, with a low $\mathrm{Si} / \mathrm{Al}$ ratio (2.4-2.8), characteristically forms from basic, alkaline glasses (low $\mathrm{Si} / \mathrm{Al}$ ), whereas deep-sea clinoptilolites, with $\mathrm{Si} / \mathrm{Al}$ ratios ranging from 4.1 to 4.9 (Boles, 1977), form from alteration of silicic glass (high $\mathrm{Si} / \mathrm{Al}$ ). The abundance of low $\mathrm{Si} / \mathrm{Al}$ ratio phillipsite $(2.49$; Table 1$)$ in the volcanogenic deposits in Hole 593 favors a primary basaltic composition.

Although we consider it most likely that the primary composition of the volcanic material was basaltic, it may be possible to speculate further that the high Ti content and $\mathrm{Ti} / \mathrm{V}$ ratios, and absence of feldspars, could indicate an alkalic, within-plate composition rather than an arc or spreading center environment (Shervais, 1982).

\section{SOURCE AND EMPLACEMENT OF VOLCANOGENIC DEPOSITS}

An Eltanin seismic profile over western Challenger Plateau (Hayes et al., 1975) had indicated the presence of a prominent sub-bottom knoll in the vicinity of proposed Site 593. While approaching Site 593 from the north, a careful watch was kept on the shipboard seismic record to ensure the chosen drill site did not sit over any such buried feature. None was located, and Hole 593 was successfully spudded and cored. However, within half an hour of departing Site 593, the seismic profiling system was again deployed to reveal the ship's eastward track passing across the eastern slope of a buried cone. This cone, named by lottery after a shipboard scientist's wife as "Lalitha pinnacle" (a Sanskrit name meaning beautiful), lay only $\sim 3 \mathrm{~km}$ from Site 593 . A seismic profile over Lalitha pinnacle (Fig. 6), recorded by Geophysics Division of New Zealand Department of Scientific and Industrial Research, Wellington, shows an edifice rising about $500 \mathrm{~m}$ from a 6-7-km-wide base. With an average profile slope of $6-8^{\circ}$, the form is compatible with that of a central basaltic shield. The downbowing of reflectors adjacent to the cone may result partly from progressive sediment infilling of a seafloor moat formed around the volcano by increased bottom current activity.

Lalitha pinnacle is logically the source of the volcanogenic deposits at Site 593, and possibly also some of the numerous thin ash layers occurring in the late Eocene-early Oligocene carbonate sediments at the site, as well as at Site 592 to the north (Gardner, Nelson, et al., this volume). It remains uncertain whether the graded volcanogenic units (Fig. 3) are cold sedimentary turbidites, each triggered by some disturbance of the volcanic materials on the slopes of Lalitha, or whether they represent discrete subaqueous pyroclastic flow deposits. Existing facies models for the latter (e.g., Tassé et al., 1978; Lajoie, 1979) closely mimic those for turbidites and associated coarse clastic sedimentary deposits (e.g., Walker, 1979), with more proximal deposits exhibiting a higher proportion of massive or reversely graded beds than distal deposits, which are mainly normally graded and include common traction structures such as horizontal and cross laminations. In either case, the majority of the normally graded volcanogenic units represent deposition at bathyal depths from relatively low-density, decelerating turbulent suspensions of basic glass-dominated material, whereas the less abundant and thicker breccia units accumulated from laminar suspensions resembling debris flows, or possibly hyaloclastites.

Based on the seismic evidence, the sequence of flows (possibly Acoustic Unit C, see Site 593 report, this volume) appears to be traceable for at least several tens of kilometers north of Site 593. Moreover, the character of the seismic profile suggests the volcanogenic deposits are probably confined to the relatively short time interval in the vicinity of the Eocene/Oligocene boundary. One slightly deeper (650-700 m sub-bottom) interval of strong reflectors (Acoustic Unit E), resembling Acoustic Unit C, does occur above acoustic basement (see Site 593 report, this volume) and may either represent earlier activity or could actually correlate with the cored volcanogenic turbidite sequence. The numerous laminae of altered volcanic ash of late Eocene through early Oligocene age at Sites 592 and 593 (Gardner, Nelson, et al., this volume) suggest when Lalitha was active. 


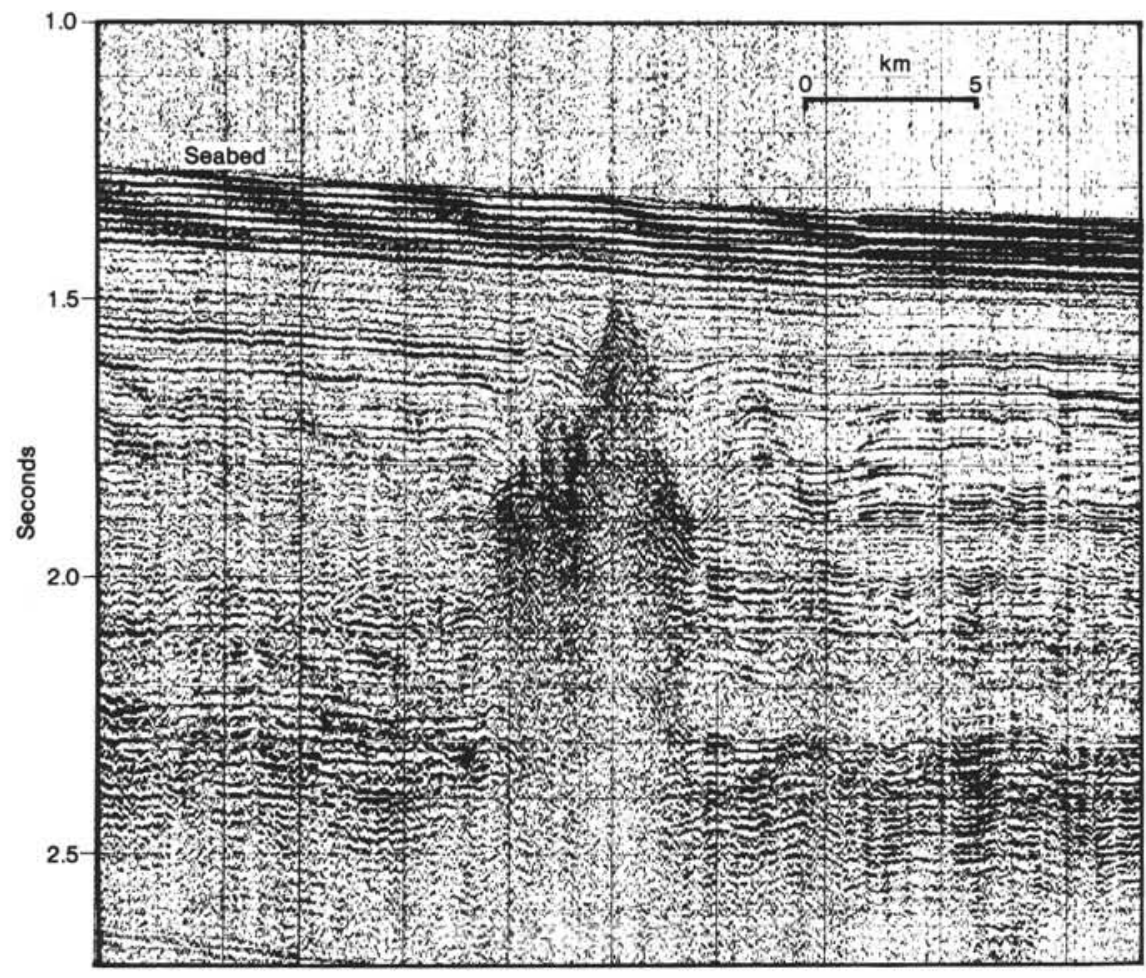

Figure 6. Single-channel seismic profile over a portion of the buried Lalitha pinnacle on western Challenger Plateau in the vicinity of Site 593 . The record was kindly provided by the Geophysics Division of the New Zealand Department of Scientific and Industrial Research, Wellington. Horizontal and vertical scales are marked at 15 -min. (approximately $3.1 \mathrm{~km}$ ) and 0.1 -s two-way traveltime (approximately $100 \mathrm{~m}$ ) intervals, respectively.

\section{EXTENT OF EOCENE-OLIGOCENE SUBMARINE VOLCANISM ON SOUTHERN LORD HOWE RISE}

A conspicuous feature of several of the published seismic reflection profiles from the southern Lord Howe Rise-Challenger Plateau region is the occurrence of isolated seafloor and buried pinnacles, resembling "piercement" structures (e.g., Brodie, 1952; Houtz et al., 1967; Andrews and Eade, 1973; Bentz, 1974; Davey, 1977). Although an igneous origin has generally been accepted for these features, considerable difference of opinion exists as to their age(s) and composition and whether they represent predominantly intrusive or extrusive masses. For example, Andrews and Eade (1973) favored an early and middle Miocene age and an intrusive origin with associated volcanism; Bentz (1974) suggested explosive rhyolitic eruptions throughout the Neogene into the present, and possibly also in the Paleogene; whereas Davey (1977) commented on some evidence for a post-Miocene age and intrusive formation.

The pinnacles typically rise a few to several hundred meters from 4-10-km-wide bases, and have calculated slopes in the range $5-12^{\circ}$. Thus, like Lalitha, they are technically not pinnacles, but, rather, have a form typical of volcanic shields. This and their association with large-amplitude, isolated, subcircular positive magnetic anomalies (van der Linden, 1967; Heirtzler et al., 1969; Bentz, 1974; Davey and Robinson, 1978) lend support to the contention that they are basaltic. In at least some cases the apparent steepness and downward continuity of pinnacles may result simply from a masking of deeperseated structures within the shadow zone cast by a cone of volcanic materials. For example, several of the subcone reflectors below the triangular top of Lalitha pinnacle appear to pass without interruption from one side of the structure to the other, suggesting that the cone was constructed from rather small, localized feeder pipes (Fig. 6).

Available seismic evidence suggests a possible correlation between several of the southern Lord Howe Rise "pinnacles" and the inferred Eocene-Oligocene basaltic volcanism represented by the buried Lalitha shield. The products of coeval volcanism on Challenger Plateau up to $500 \mathrm{~km}$ from Site 593 are evident on Eltanin seismic Profiles 26 and 34 (e.g., Fig. 7). Here the volcanics are closely associated with a prominent reflector (labeled X by Davey, 1977) which, in the vicinity of Site 593, corresponds to an unconformity of late Eocene and/or early Oligocene age (see Site 593 seismic stratigraphy, this volume). Away from Site 593 this unconformity becomes more profound (e.g., top middle Eocene to base middle Miocene at DSDP Site 207; Kennett et al., 1975) and corresponds to a well-documented regional PaleogeneNeogene unconformity in the Tasman Sea (Bentz, 1974; Kennett et al., 1975). Seismic profiles from the southern Lord Howe Rise (e.g., Houtz et al., 1967; Andrews and Eade, 1973; Bentz, 1974), $500 \mathrm{~km}$ and more north of Site 593 (Fig. 8), also show that isolated (volcanic) pinnacles are sometimes associated with this unconformity. For example, Houtz et al. (1967, p. 4726) noted that the 

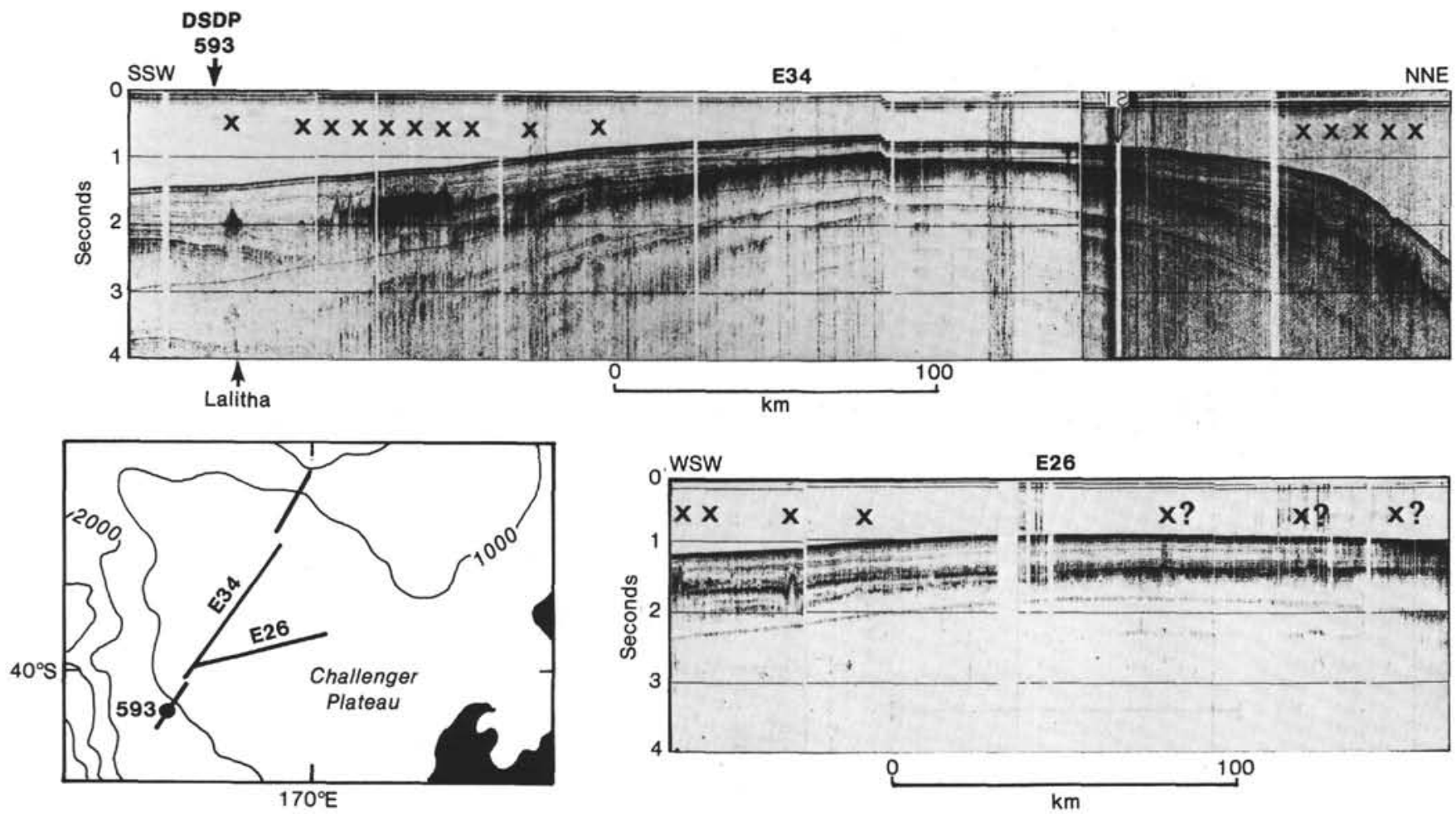

Figure 7. Portions of Eltanin seismic tracks 26 and 34 (adapted from Houtz and Aitkin, 1973; and Hayes et al., 1975) in the vicinity and northeast of Site 593 showing Lalitha pinnacle and other probably correlative buried basaltic volcanoes (marked by overlying crosses) on Challenger Plateau. Other seismic examples of volcanic features from as far as $500 \mathrm{~km}$ and more north of these profiles are illustrated by Houtz et al. (1967), Andrews and Eade (1973), and Bentz (1974). Bathymetry on locality map in meters.

"volcanics have poured out on a surface... which appears to correlate with the unconformity," whereas Andrews and Eade (1973, p. 3095) indicated that the volcanics "have been buried by sediments above the reflector," which corresponds to the mid-Eocene to mid-Miocene unconformity.

Obviously considerably more specific seismic and drill core data are needed to resolve the origin(s) of these (buried) pinnacles. However, their seismic character and structural and age relations to surrounding sediments, which are similar to those of Lalitha pinnacle, suggest that submarine basaltic volcanism was scattered but widespread over at least $250,000 \mathrm{~km}^{2}$ in the southeast Tasman Sea region during late Eocene to early Oligocene times.

\section{TECTONIC IMPLICATIONS OF LATE EOCENE-EARLY OLIGOCENE SUBMARINE VOLCANISM}

The similar character and age of the widely distributed submarine volcanics over the southern Lord Howe Rise and Challenger Plateau are suggestive of a regional tectonic control on their eruption. A subduction origin of these basalts, either as island arc or back-arc volcanics, is precluded by the location and orientation of the nearest trench at that time, the Tonga-Kermadec Trench (Kamp, 1984). The widespread eruption of these volcanics near the Eocene/Oligocene boundary also precludes any suggestion of migratory control, as established for Cenozoic volcanics in eastern Australia by Wellman and McDougall (1974) and Sutherland (1981). The loca- tion of the submarine volcanics above the Lord Howe Rise rift system and adjacent to the New Caledonia Basin (Fig. 8) may, however, be indicative of a rift-related origin.

That there is not a simple and direct relationship between the basaltic eruptions and either the Lord Howe Rise or New Caledonia Basin rifting is evident from the great disparity in ages between rifting and volcanism. In both cases active rifting preceded Tasman Sea spreading, dated from 76-57 m.y. ago (Jongsma and Mutter, 1978; Wilcox et al., 1980), whereas the basaltic volcanism occurred near the Eocene/Oligocene boundary. The occurrence of the volcanics upon Paleogene bathyal nannofossil chalk also indicates that the eruptions followed passive foundering of the Lord Howe Rise, which in turn postdated the active rifting.

We consider that the submarine volcanism originated from the reactivation of underlying Late Cretaceous rift structures. That these faults were reactivated in the late Eocene-Oligocene can be inferred from the seismic sections presented by Bentz (1974). He showed that many of the basement faults within what later came to be identified as the Lord Howe Rise rift system (Jongsma and Mutter, 1978), and on the eastern flank of the New Caledonia Basin, extended through the Paleogene sequence up to the widespread Paleogene-Neogene unconformity in the Tasman Sea (Kennett et al., 1975), of which the underlying beds are variously aged from middle Eocene to early Oligocene. Bentz (1974) considered that these faults originated by differential displacements as the Lord Howe Rise foundered through the Paleogene. This is chal- 


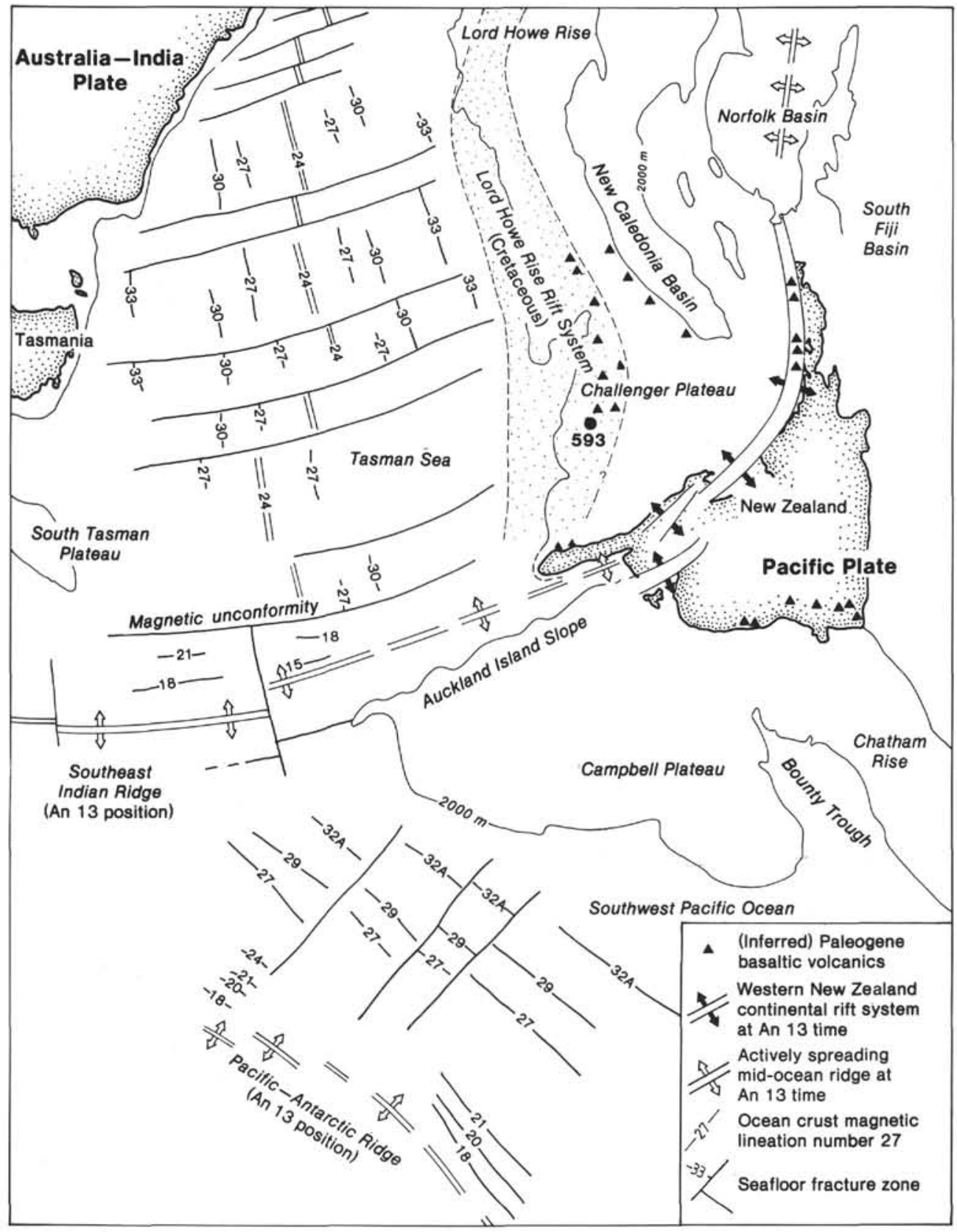

Figure 8. Plate tectonic reconstruction of the Tasman Sea-southwest Pacific region at Anomaly (An) 13 time ( 37 m.y. ago), during eruption of the DSDP Site 593 Eocene/Oligocene boundary volcanics, showing the distribution of these and other possible (offshore geophysical evidence) and definite (on land in New Zealand) early Tertiary basaltic volcanoes in the region in relation to spreading on the Southeast Indian Ridge and the postulated New Zealand continental rift system of the time.

lenged on the basis that there is no perceptible evidence of sequences below the unconformity thickening toward growth faults, as one would expect. Also, closely spaced faulting would not be consistent with the evidence from other passive margins (e.g., Montadert et al., 1979) that subsidence of a continental margin following rifting is not characterized by differential faulting, nor with geophysical modeling that suggests that the flexural rigidity of continental crust increases after rifting (Karner and Watts, 1982). We prefer to interpret the faults cutting the Paleogene sequence in Bentz's (1974) sections as mainly postdepositional faults that displaced the lower Paleo- gene sequence vertically, thereby facilitating the rapid upward passage of basaltic magmas and subsequently their extrusion.

We propose that the reactivation of the rift structures was a local response to the regional extension accompanying a middle to late Eocene change in the seafloor spreading pattern southwest of New Zealand. Kamp (unpubl. data) has suggested that following the cessation of Tasman Sea spreading, the Southeast Indian Ridge propagated eastward into the New Zealand subcontinent during the middle to late Eocene (Anomaly 18-Anomaly 13) and caused the development of a continental rift sys- 
tem through western New Zealand (Fig. 8). Coincidentally, the Eocene/Oligocene boundary age of the transition from slow infrarift subsidence to active axial trough subsidence in the western rift system is the same age as the submarine volcanism, as determined previously. The vigorous eastward propagation of the mid-ocean ridge into New Zealand and the associated continental rifting offer a compelling geodynamic reason for the reactivation of the Late Cretaceous structures of the Lord Howe Rise-Challenger Plateau. This mechanism may also explain the occurrence of Eocene-Oligocene submarine basaltic lavas and tuffs of tholeiitic to alkaline composition in eastern South Island (Schofield, 1951; Coombs and Dickey, 1965; Challis, 1978); these are disposed off the rift to the east the same distance $(\sim 300 \mathrm{~km})$ as the Lord Howe Rise and Challenger Plateau volcanics are to the west (Fig. 8).

\section{CONCLUSIONS}

1. A 16.4-m-thick sequence of volcanogenic deposits is enclosed within bathyal chalks about $550 \mathrm{~m}$ below the seafloor at DSDP Site 593, western Challenger Plateau, Tasman Sea.

2. The sequence of deposits was emplaced rapidly at bathyal depths close to the time of the Eocene/Oligocene boundary, about 37-36 m.y. ago.

3. It consists of a stacked series of normally graded volcanogenic sandstone-mudstone couplets with Bouma sequences of sedimentary structures, indicating deposition from decelerating turbidity currents, and occasional thicker interbeds of massive or inversely graded, unsorted volcanogenic breccia, suggestive more of deposition from high-concentration laminar suspensions resembling debris flows. It is not possible, based on present evidence, to distinguish positively between cold sedimentary redeposition or subaqueous pyroclastic flow origins for the beds, since generally similar structures can result from both emplacement mechanisms.

4. Petrographic, chemical, and geophysical data supports a basaltic heritage for the sequence. However, the original glassy components that formed the bulk of the deposits have been pervasively palagonitized and replaced by a complex association of the secondary minerals phillipsite, smectite, and calcite as a result of low-temperature oxidative alteration by pore fluids. It is inferred that alteration commenced soon after emplacement of the deposits and has continued throughout burial diagenesis.

5. The probable source of the deposits is Lalitha pinnacle, a now-buried 500-m-high volcanic shield situated near Site 593.

6. Seismic evidence indicates that volcanic centers of similar character and age to Lalitha pinnacle are dotted over at least $250,000 \mathrm{~km}^{2}$ of southern Lord Howe Rise and Challenger Plateau. This implies that submarine basaltic volcanism and associated sedimentary redeposition were widespread in the southeast Tasman Sea region during the late Eocene to early Oligocene. Previously, this period has been regarded as one of little volcanism in the area.

7. Volcanism is genetically related to the eastward propagation in the late Eocene-early Oligocene of the mid- ocean Southeast Indian Ridge into the south Tasman Sea and through the New Zealand subcontinent, forming a major western New Zealand rift system. The southern Lord Howe Rise basalts are viewed as off-rift (western) volcanics erupted along reactivated major Late Cretaceous faults on the Rise in response to regional extension across the New Zealand platform accompanying development of the western rift system. Analogous occurrences of submarine Eocene-Oligocene basalts east of the rift system now crop out on land in eastern South Island, New Zealand.

\section{ACKNOWLEDGMENTS}

We thank Drs. P. F. Ballance, Geology Department, University of Auckland; F. J. Davey, Geophysics Division, Department of Scientific and Industrial Research, Wellington; J. B. Gill, University of California, Santa Cruz; and J. H. Natland, Scripps Institution of Oceanography, for constructive reviews of this manuscript. The age data forming Figure 5 were kindly provided by Dr. W. H. Lohman (Marathon Oil Company, Denver) and the core photographs of Figures 2 and 4 were prepared aboard ship by Mr. V. Sotelo.

\section{REFERENCES}

Andrews, J. E., and Eade, J. V., 1973. Structure of the western continental margin, New Zealand, and the Challenger Plateau, eastern Tasman Sea. Geol. Soc. Am. Bull., 84:3093-3100.

Bentz, F. P., 1974. Marine geology of the southern Lord Howe Rise, Southwest Pacific. In Burk, C. A., and Drake, C. L. (Eds.), The Geology of Continental Margins: New York (Springer-Verlag), pp. 537-547.

Boles, J. R., 1977. Zeolites in deep-sea sediments. In Mumpton, F. A. (Ed.), Reviews in Mineralogy (Vol. 4) Mineralogy and Geology of Natural Zeolites: Mineral. Soc. Am., pp. 137-163.

Brodie, J. W., 1952. Features of the sea-floor west of New Zealand. N.Z. J. Sci. Technol., B33:373-384.

Campsie, J., Neumann, E. R., and Johnson, L., 1983. Dredged volcanic rocks from the southern oceans: the Eltanin collection. $N$. Z. J. Geol. Geophys., 26:31-45.

Carter, R. M., 1975. A discussion and classification of subaqueous mass-transport with particular application to grain-flow, slurry-flow, and fluxoturbidites. Earth Sci. Rev., 11:145-177.

Challis, G. A., 1978. (Tertiary) Volcanism. In Suggate, R. P., Stevens, G. R., and Te Punga, M. T. (Eds.), The Geology of New Zealand: Wellington (Govt. Printer), pp. 632-637.

Coombs, D. S., and Dickey, J. S., 1965. The early Tertiary petrographic province of north-east Otago: Waiareka and Deborah Volcanic formations. N. Z. Volcanol. South Island. N. Z. Dept. Sci. Industr. Res. Info. Ser., 51:38-50.

Davey, F. J., 1977. Marine seismic measurements in the New Zealand region. N. Z. J. Geol. Geophys., 20:719-777.

Davey, F. J., and Robinson, A. G., 1978. Cook (1st Ed.). Magnetic total force anomaly map, Oceanic Series, 1:1000 000. Wellington, N. Z., Dept. Sci. Indust. Res.

Gill, J. B., 1981. Orogenic Andesites and Plate Tectonics: Berlin (Springer-Verlag).

Hart, R., 1970. Chemical exchange between sea water and deep ocean basalts. Earth Planet. Sci. Lett., 9:269-279.

Hay, R. L., and Iijima, A., 1968. Nature and origin of palagonite tuffs of the Honolulu Group on Oahu, Hawaii. Geol. Soc. Am. Mem., 116:331-376.

Hayes, D. E., Houtz, R., Talwani, M., Watts, A. B., Weissel, J., and Aitken, T., 1975. Preliminary Report of Volume 23, USNS Eltanin, Cruises 33-38, March 1968-May 1969. Parts A, B and C. Tech. Rept. Lamont-Doherty Geol. Obs. Columbia Univ., Palisades, $N$. Y., Cu-1-75.

Heirtzler, R. J., Hayes, D. E., Herron, E. M., and Pitman, W. C., III, 1969. Preliminary Report of Volume 20, USNS Eltanin, Cruises 16-21, January 1965-January 1966. Parts A and B. Tech. Rept. Lamont-Doherty Geol. Obs., Columbia Univ., Palisades, N. Y., 3CU-3-69.

Houtz, R., and Aitkin, T. D., 1973. Preliminary Report of Volumes 20 and 21, USNS Eltanin Cruises 16-21 and 22-27, January 1965- 
February 1967. Part C. Tech. Rept. Lamont-Doherty Geol. Obs., Columbia Univ., Palisades, N. Y., CU-1-73.

Houtz, R. E., Ewing, J., Ewing, M., and Leonard, A. G., 1967. Seismic reflection profiles of the New Zealand Plateau. J. Geophys. Res., 72:4713-4739.

Jongsma, D., and Mutter, J. C., 1978. Non-axial breaching of a rift valley: evidence from the Lord Howe Rise and the southeastern Australian margin. Earth Planet. Sci. Lett., 39:226-234.

Kamp, P. J. J., 1984. Neogene and Quaternary extent and geometry of the subducted Pacific Plate beneath North Island, New Zealand: implications for Kaikoura tectonics. Tectonophysics, 108:241-266.

Karner, G. D., and Watts, A. B., 1982. On isostasy at Atlantic-type continental margins. J. Geophys. Res., 87:2923-2948.

Kastner, M., 1979. Zeolites. In Burns, R. G. (Ed.), Reviews in Mineralogy (Vol. 6) Marine Minerals: Mineral. Soc. Am., pp. 111-122.

Kennett, J. P., Houtz, R. E., Andrews, P. B., Edwards, A. R., Gostin, V. A., Hajòs, M., Hampton, M., Jenkins, D. G., Margolis, S. V., Ovenshine, A. T., and Perch-Nielsen, K., 1975. Cenozoic paleoceanography in the southwest Pacific Ocean, Antarctic glaciation, and the development of the Circum-Antarctic Current. In Kennett, J. P., Houtz, R. E., et al., Init. Repts. DSDP, 29: Washington (U.S. Govt. Printing Office), 1155-1169.

LaBrecque, J. L., Hsü, K. J., Carman, M. F., Jr., Karpoff, A-M., McKenzie, J. A., Percival, S. F., Jr., Petersen, N. P., Pisciotto, K. A., Schreiber, E., Tauxe, L., Tucker, P., Weissert, H. J., and Wright, R., 1983. DSDP Leg 73: contributions to Palaeogene stratigraphy in nomenclature, chronology and sedimentation rates. Palaeogeogr., Palaeoclimatol., Palaeoecol., 42:91-125.

Lajoie, J., 1979. Facies models 17 . Volcaniclastic rocks. In Walker, R. G. (Ed.), Facies Models: Canada (Geoscience Canada), Repr. Ser. 1, pp. 191-200.

Leggett, J. K., 1982. Drilling-induced structures in Leg 66 cores. In Watkins, J. S., Moore, J. C., et al., Init. Repts. DSDP, 66: Washington (U.S. Govt. Printing Office), 531-532.

Le Roex, A. P., and Dick, H. J. B., 1981. Petrography and geochemistry of basaltic rocks from the Conrad fracture zone on the America-Antarctic Rise. Earth Planet. Sci. Lett., 54:117-138.

Montadert, L., de Charpal, O., Roberts, D. G., Guennoc, P., and Sibuet, J.-C., 1979. Northeast Atlantic passive margins: rifting and subsidence process. In Talwani, M., Hay, W. W., and Ryan, W. B. F. (Eds.), Deep Drilling Results in the Atlantic Ocean: Continental Margins and Paleo-environment. Am. Geophys. Un., Maurice Ewing Ser., 3:154-186.

Petzing, J., and Chester, R., 1979. Authigenic marine zeolites and their relationship to global volcanism. Marine Geol., 29:253-271.

Poore, R. Z., Tauxe, L., Percival, S. F., Jr., LaBrecque, J. L., Wright, R., Petersen, N. P., Smith, C. C., Tucker, P., and Hsü, K. J., 1983. Late Cretaceous-Cenozoic magnetostratigraphic and biostratigraphic correlations of the South Atlantic Ocean: DSDP Leg 73. Palaeogeogr., Palaeoclimatol., Palaeoecol., 42:127-149.

Scheidegger, K. F., and Corliss, J. B., 1981. Petrogenesis and secondary alteration of upper layer 2 basalts of the Nazca plate. Geol. Soc. Am. Mem., 154:77-107.

Schofield, J. C., 1951. Distribution of lower Oligocene volcanics in New Zealand. N. Z. J. Sci. Technol., B33:201-217.

Shervais, J. W., 1982. Ti-V plots and the petrogenesis of modern and ophiolitic lavas. Earth Planet. Sci. Lett., 59:101-118.

Sutherland, F. L., 1981. Migration in relation to possible tectonic and regional controls in eastern Australian volcanism. J. Volcanol. Geotherm. Res., 9:181-213.

Tassé, N., Lajoie, J., and Dimroth, E., 1978. The anatomy and interpretation of an Archean volcaniclastic sequence, Noranda region, Quebec. Can. J. Earth Sci., 15:874-888.

van der Linden, W. J. M., 1967. Structural relationships in the Tasman Sea and south-west Pacific Ocean. N. Z. J. Geol. Geophys., 10: 1280-1301.

Walker, R. G., 1979. Facies Models 8. Turbidites and associated coarse clastic deposits. In Walker, R. G. (Ed.), Facies Models: Canada (Geoscience Canada), Repr. Ser. 1, pp. 91-103.

Wellman, P., and McDougall, I., 1974. Cenozoic igneous activity in eastern Australia. Tectonophysics, 23:49-65.

Wilcox, J. B., Symonds, P. A., Hinz, K., and Bennett, D., 1980. Lord Howe Rise, Tasman Sea-preliminary geophysical results and petroleum prospects. BMR J. Austral. Geol. Geophys., 5:225-236.

Date of Initial Receipt: 14 May 1984

Date of Acceptance: 31 October 1984 


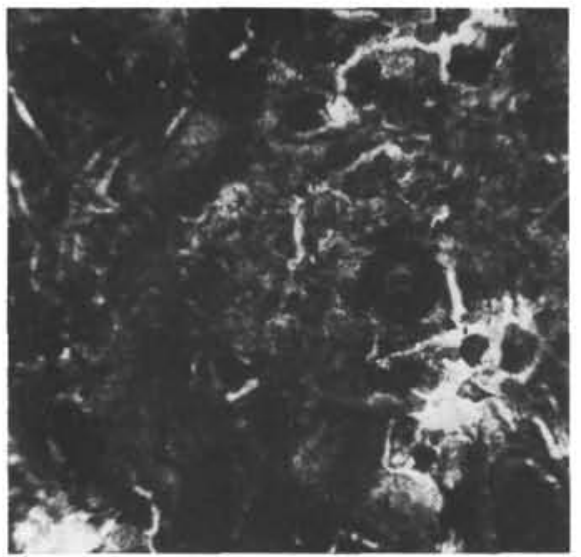

1

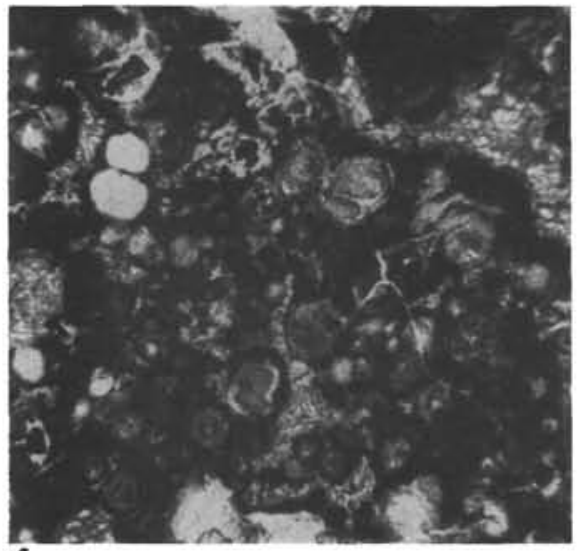

4

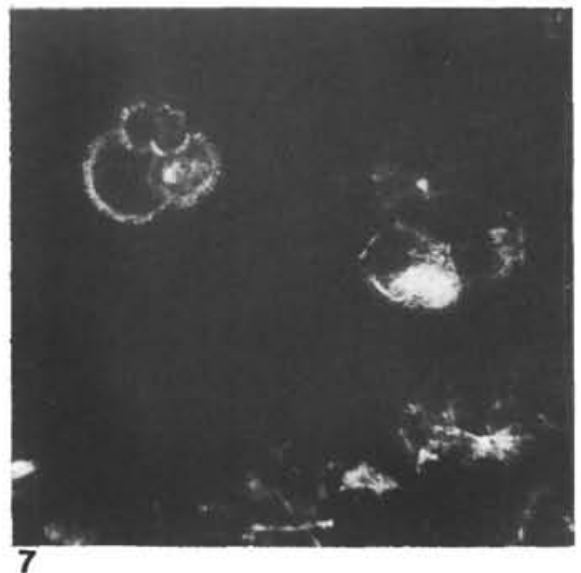

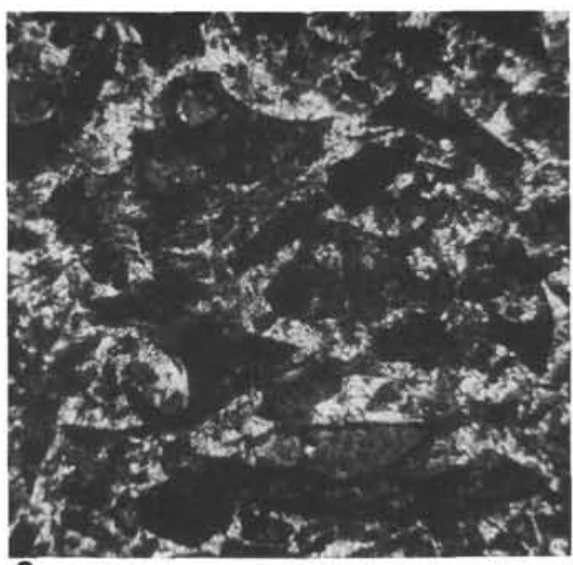

\section{2}

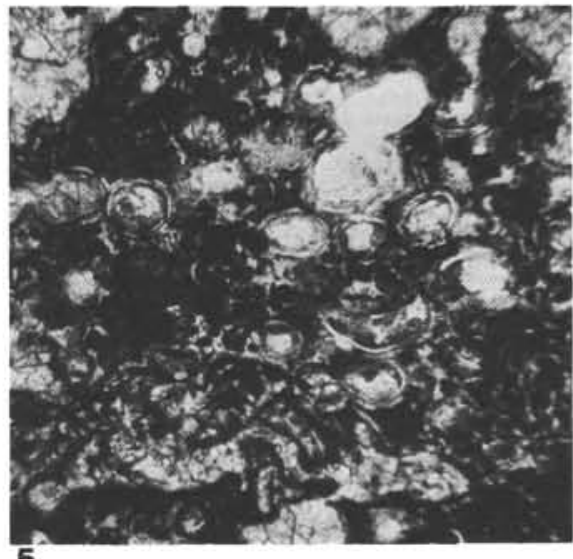

5

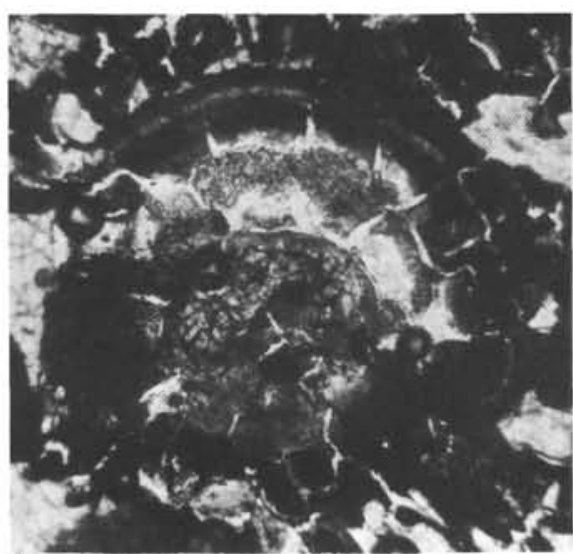

8
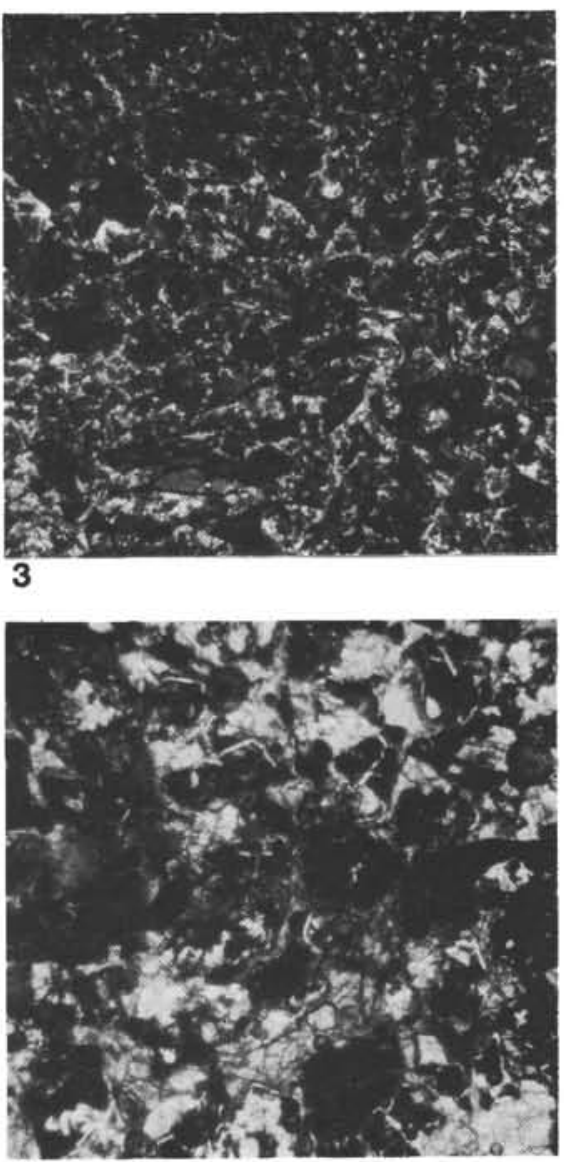

6

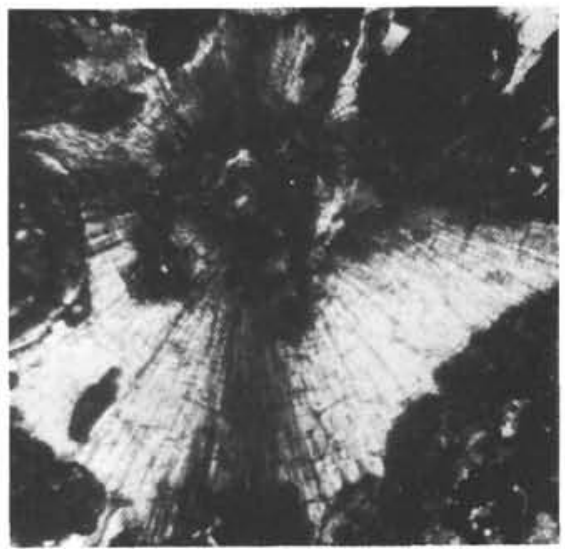

9

Plate 1. Photomicrographs (1-8, plane polarized light; 9, crossed-nicols) of altered volcanogenic material at Site 593. For Figs. 1, 2, 4, 7, 8, and 9 the bottom edge of the photomicrograph measures $0.7 \mathrm{~mm}$; for Figs. 3, 5, and 6 about $1.7 \mathrm{~mm}$. 1. Palagonite masses (black or dark gray) with irregular patches and veinlets of calcite and phillipsite (white or light gray). 2. Relict, cuspate, curved glass shards set in a calcite-phillipsite cement. 3. Lithologic layering defined by palagonitized, fine (top), and coarse shard-rich bands; light-colored cement is mainly calcite, phillipsite, and smectite. 4. Globular masses of palagonitic material with smectite, calcite, and phillipsite in concentric layers within globules, and surrounded by coarse-grained sparry calcite. 5. Globular palagonite in sparry calcite cement. 6. Palagonite masses in a cement of calcite, phillipsite, and smectite. 7. Black palagonite-rich layer containing planktonic foraminifers. 8. Radial and concentric perlitic cracks in globular palagonite containing secondary minerals in concentric layers. 9. Radiating splay of phillipsite. 